\title{
Intranasal Delivery of a Methyllanthionine-Stabilized Galanin Receptor-2-Selective Agonist Reduces Acute Food Intake
}

\author{
Anneke Kuipers ${ }^{1} \cdot$ Márta Balaskó $^{2}$ - Erika Pétervári' ${ }^{2}$ Andreas Koller ${ }^{3,4} \cdot$ Susanne M. Brunner ${ }^{3,4} \cdot$ Gert N. Moll $^{1,5}$. \\ Barbara Kofler ${ }^{3}$ iD
}

Accepted: 30 October 2021 / Published online: 2 December 2021

(c) The Author(s) 2021

\begin{abstract}
The regulatory (neuro)peptide galanin is widely distributed in the central and peripheral nervous systems, where it mediates its effects via three $\mathrm{G}$ protein-coupled receptors $\left(\mathrm{GAL}_{1-3} \mathrm{R}\right)$. Galanin has a vast diversity of biological functions, including modulation of feeding behavior. However, the clinical application of natural galanin is not practicable due to its rapid in vivo breakdown by peptidases and lack of receptor subtype specificity. Much effort has been put into the development of receptor-selective agonists and antagonists, and while receptor selectivity has been attained to some degree, most ligands show overlapping affinity. Therefore, we aimed to develop a novel ligand with specificity to a single galanin receptor subtype and increased stability. To achieve this, a lanthionine amino acid was enzymatically introduced into a galanin-related peptide. The residue's subsequent cyclization created a conformational constraint which increased the peptide's receptor specificity and proteolytic resistance. Further exchange of certain other amino acids resulted in a novel methyllanthionine-stabilized galanin receptor agonist, a G1pE-T3N-S6A-G12A-methyllanthionine[13-16]-galanin-(1-17) variant, termed M89b. M89b has exclusive specificity for $\mathrm{GAL}_{2} \mathrm{R}$ and a prolonged half-life in serum. Intranasal application of $\mathrm{M} 89 \mathrm{~b}$ to unfasted rats significantly reduced acute $24 \mathrm{~h}$ food intake inducing a drop in body weight. Combined administration of M89b and M871, a selective $\mathrm{GAL}_{2} \mathrm{R}$ antagonist, abolished the anorexigenic effect of M89b, indicating that the effect of M89b on food intake is indeed mediated by $\mathrm{GAL}_{2} \mathrm{R}$. This is the first demonstration of in vivo activity of an intranasally administered lanthipeptide. Consequently, M89b is a promising candidate for clinical application as a galanin-related peptide-based therapeutic.
\end{abstract}

Keywords Lanthionine $\cdot$ Ligand $\cdot$ GPCR $\cdot$ Neuropeptide $\cdot$ Lactococcus $\cdot$ Feeding

Barbara Kofler

b.kofler@salk.at

1 Lanthio Health B.V., Rozenburglaan 13B, 9727 DL Groningen, Netherlands

2 Institute for Translational Medicine, Medical School, University of Pécs, 12 Szigeti út, H-7624 Pécs, Hungary

3 Research Program for Receptor Biochemistry and Tumor Metabolism, Department of Pediatrics, University Hospital of the Paracelsus Medical University, Muellner Hauptstr. 48, 5020 Salzburg, Austria

4 Research Program for Experimental Ophthalmology, Department of Ophthalmology and Optometry, University Hospital of the Paracelsus Medical University, Salzburg, Austria

5 Department of Molecular Genetics, Groningen Biomolecular Sciences and Biotechnology Institute, University of Groningen, Nijenborgh 7, 9747 AG Groningen, Netherlands

\section{Introduction}

Galanin is a 29 amino acid peptide that was first isolated from porcine intestine in 1983 [1] and was later found in many other species, displaying a high degree of conservation of the $\mathrm{N}$-terminal part. Human galanin is unique in that it consists of 30 amino acids and, in contrast to other species, does not undergo amidation at the $\mathrm{C}$-terminus.

Typical for regulatory peptides, galanin is derived from a 123 (human)/124 (murine) amino acid preproprecursor molecule. Proteolytic cleavage results in the mature galanin peptide. Consistent with the classic definition of neuropeptides, galanin is widely distributed in both the central and peripheral nervous systems; however, it is also found in non-neuronal peripheral tissues. In the 37 years since its discovery, a vast diversity of biological functions have been described for galanin, including roles in modulation of neurotransmission, nociception, learning and memory, anxiety 
and related behaviors, immunity and inflammation, neuronal injury and survival, regeneration, and neuroprotection (for review see [2, 3]). Recently, we demonstrated that galanin is a modulator of immune cell function [4-7]. Furthermore, central administration of galanin produced a rapid increase in food intake [8-12]. Acute effects of galanin on feeding were abolished by galanin receptor (GALR) antagonists [11]. Initially, neither $\mathrm{GAL}_{1} \mathrm{R}-\mathrm{KO}$ nor $\mathrm{GAL}_{2} \mathrm{R}-\mathrm{KO}$ mice were reported to display any marked phenotype related to differences in body weight or feeding behavior [13-15]. However, subsequent studies indicated that the endogenous galanin- $\mathrm{GAL}_{1} \mathrm{R}$ system plays a role in adjusting food intake and/or metabolism to acute changes in dietary fat $[16,17]$.

Galanin exerts its biological effects by signaling via $G$ protein-coupled receptors (GPCRs). To date, three endogenous GALRs have been identified and termed $\mathrm{GAL}_{1-3} R$. Each receptor subtype shows high interspecies homology, but the three GALRs are only moderately homologous to each other. They differ in their tissue-specific expression pattern and, most importantly, in their functional coupling and signal transduction pathways, which contributes to the diversity of galanin-mediated effects [3]. $\mathrm{GAL}_{1} \mathrm{R}$ couples to $\mathrm{G}_{\mathrm{i}}$-type $\mathrm{G}$ proteins, resulting in inhibition of cAMP production, opening of $\mathrm{G}$ protein-regulated inwardly rectifying $\mathrm{K}^{+}$ (GIRK) channels, and stimulation of mitogen-activated protein kinase (MAPK) activity. $\mathrm{GAL}_{2} \mathrm{R}$ signals through multiple classes of $G$ proteins and stimulates multiple intracellular pathways; however, it preferentially couples to $G_{q / 11^{-t y p e}}$ $\mathrm{G}$ proteins, leading to phospholipase $\mathrm{C}$ activation, which stimulates $\mathrm{Ca}^{2+}$ release via inositol phosphate hydrolysis and opens $\mathrm{Ca}^{2+}$-dependent ion channels in a pertussis toxin (PTX)-resistant manner. Evidence from various in vitro and in vivo studies also shows $\mathrm{GAL}_{2} \mathrm{R}$ coupling to $\mathrm{G}_{\mathrm{i} / \mathrm{o}^{-}}$and $\mathrm{G}_{12 / 13}$-type $\mathrm{G}$ proteins. The signaling properties of $\mathrm{GAL}_{3} \mathrm{R}$ are still poorly defined. $\mathrm{GAL}_{3} \mathrm{R}$ appears to act mainly via PTX-sensitive $\mathrm{G}_{\mathrm{i} / \mathrm{o}}$-type $\mathrm{G}$ proteins, resulting in activation of GIRK channels as well as decreased adenylate cyclase activity and cytosolic cAMP levels. In addition, potential heteromerization of GALRs has been proposed [18, 19].

Since the discovery of the three GALRs, major effort has been directed at developing receptor-selective agonists and antagonists. These were based on substitution of certain amino acids in the galanin peptide sequence. While receptor selectivity was achieved to some degree, GAL(2-11) turned out to be a very selective non-GAL $\mathrm{R}_{1}$ agonist. Most of the other analogs showed overlapping affinity [3]. We showed that Ala5-galanin(2-11) is effectively a $\mathrm{GAL}_{2} \mathrm{R}$-specific agonist, with a more than 375 -fold preference for $\mathrm{GAL}_{2} \mathrm{R}$ compared to both $\mathrm{GAL}_{1} \mathrm{R}$ and $\mathrm{GAL}_{3} \mathrm{R}$ [20].

The use of natural galanin in clinical applications faces two serious limitations: lack of receptor specificity and in vivo susceptibility to rapid peptidase-mediated breakdown. Endogenous galanin displays no receptor specificity, but its affinity to each receptor subtype varies $\left(G_{1} L_{1} R>G A L_{2} R>G A L_{3} R\right.$ ) (for review see [2]). Interestingly, only the first 15 amino acids of the $\mathrm{N}$-terminal part of the peptide are important for the interaction with galanin receptors. Recently, a selective $\mathrm{GAL}_{2} \mathrm{R}$ agonist based on the sequence of spexin, a newly discovered natural peptide with affinity for $\mathrm{GAL}_{2} \mathrm{R}$ and $\mathrm{GAL}_{3} \mathrm{R}$, was reported to have a halflife of about $8 \mathrm{~h}$ in serum [21]. In vitro biostability studies revealed that the half-life of synthetic galanin in cerebrospinal fluid is 60 to $120 \mathrm{~min}$ [22]. The in vivo half-life of galanin in plasma is around 4 min [23, 24]. In view of this short in vivo half-life, galanin analogs with increased stability are needed to achieve therapeutic potential.

A promising alternative could be the introduction of lanthionines into galanin analogs, which may enhance receptor specificity and stability. Lanthionine (alanine-sulfur-alanine) is a highly stable, monosulfide bridge-containing amino acid. Cyclization by the methyllanthionine structure leads to a conformational constraint. Owing to this constraint, the receptor specificity may increase, and the peptide becomes resistant to breakdown by peptidases, leading to a prolonged in vivo half-life and potentially broader delivery options [25-28]. For example, a lanthionine-stabilized angiotensin-(1-7) has strongly increased resistance to peptidases and has shown therapeutic efficacy in animal models of cardiovascular, metabolic, kidney, and pulmonary disease [29-32].

For delivery of therapeutic peptides and proteins to the brain, the blood-brain barrier (BBB) is a major impediment. Intranasal delivery might provide a non-invasive means to bypass the BBB. Advantages of applying peptides via the nasal route, provided they do indeed reach the brain, include minimizing exposure to peripheral organs and tissues, thus reducing systemic side effects. It also allows peptides, which typically undergo both rapid degradation in the blood and excretion, sufficient time to exert their effect. Intranasal delivery of peptides may provide the ability to target specific regions of the brain when administered with substrates like cyclodextrins $[33,34]$. Indeed, the use of cyclodextrins has been one of the most successful approaches to target peptides to various brain regions. Cyclodextrins have long been used in nasal drug delivery as adsorption-enhancing compounds to increase the intranasal bioavailability of protein and peptide drugs $[33,35]$. Recent studies have revealed that intranasally applied galanin-like peptide (GALP), which is an endogenous ligand of GALRs, has a central anti-obesity action in addition to its role in food intake regulation [36]. Intranasal administration of GALP with $\alpha$-cyclodextrins increased uptake in all brain regions by two- to threefold compared to GALP alone [36].

With the overall goal of developing galanin-based peptidergic drugs for clinical applications, the aim of the present study was to create a stable galanin analog with strict specificity to a single GALR subtype. We hypothesized that 
introduction of a pyroglutamate and methyllanthionine into galanin would enhance the peptide's receptor specificity and stability.

Here, we report on the introduction of a methyllanthionine into C-terminally truncated galanin analogs by employing Lactococcus lactis bacteria that contain methyllanthionine-installing enzymes. To protect the peptides against breakdown by most aminopeptidases, a pyroglutamate was induced [37]. From 49 produced peptides, the G1pET3N-S6A-G12A-methyllanthionine[13-16]-galanin-(1-17) variant, termed M89b, was selected as our lead compound. M89b displays enhanced in vitro stability and unique $\mathrm{GAL}_{2} \mathrm{R}$ specificity. As a neuropeptide analog, we evaluated the in vivo activity of M89b following intranasal delivery.

\section{Methods}

\section{Galanin Peptides}

GAL-(1-15) was purchased from Tocris (Bio-Techne) and dissolved in water. For the production of methyllanthioninestabilized galanin variants, Lactococcus lactis (L. lactis) harboring the two plasmids pIL3BTC and pNZM89bNdei was cultured. Plasmid pNZM89bNdei encodes the sequence for the substrate peptide fusion used for M89b. For example, for the case of M89b, this fusion peptide is composed of three parts, (1) the N-terminal 23 amino acid nisin leader peptide, (2) the export-enhancing $\mathrm{N}$-terminal nisin-related part ITSISLCTPGCKTGAHMIE ending with a glutamate to allow cleavage by Glu-C, and (3) the C-terminally truncated galanin mutant QWNLNAAGYLLATHACG, which contains G1Q, T3N, S6AG12A, P13T, and V16C substitutions: MSTKDFNLDLVSVSKKDSGASPR-ITSISLCTPGCKTGAHMIE-QWNLNAAGYLLATHACG. Plasmid pIL3BTC encodes the genes for the lanthionine-installing enzymes NisB, which harbors the genes for the lanthionine-installing enzymes dehydrates threonine13 yielding dehydrobutyrine13, and $\mathrm{NisC}$, which subsequently catalyzes the coupling of dehydrobutyrine 13 to cysteine 16 to form a methyllanthionine, and the transporter NisT, which exports the modified peptide into the culture medium [37].

L. lactis pIL3BTC pNZM89bNdei was grown overnight at $30{ }^{\circ} \mathrm{C}$ in M17 broth [38] supplemented with $0.5 \%$ glucose and chloramphenicol $(5 \mu \mathrm{g} / \mathrm{mL})$ and erythromycin $(5 \mu \mathrm{g} / \mathrm{mL})$. The overnight culture was diluted 100 -fold in minimal medium [39] supplemented with glucose. To induce transcription of the genes encoding the fusion peptide, modification enzymes and the transporter, the nisin promoter-controlled nisin leader peptide galanin fusion and modifications and to export enzymes, the supernatant of the nisin-producing strain NZ9700 (1:1000) was added, and the culture was grown further for $24 \mathrm{~h}$ at $30{ }^{\circ} \mathrm{C}$. Cellfree supernatant from the 4-L culture was equilibrated with
1 volume $100 \mathrm{mM}$ lactic acid. Peptides $(4 \times 5 \mathrm{ml})$ were bound to HiTrap SP columns (GE Healthcare), washed with $50 \mathrm{mM}$ lactate buffer $\mathrm{pH} 4$, and eluted with $50 \mathrm{mM}$ lactate buffer containing $1 \mathrm{M} \mathrm{NaCl}$ and $6 \mathrm{M}$ urea. The eluted fractions were desalted by passage over PD-10 gel filtration columns (GE Healthcare). To cleave off the formed lanthi-galanin, the isolated fusion peptides were incubated in $100 \mathrm{mM}$ phosphate buffer $\mathrm{pH} 7.6$ supplemented with 250 U endoproteinase Glu-C V8 Protease (Merck) overnight at $37^{\circ} \mathrm{C}$. During the latter incubation, the $\mathrm{N}$-terminal glutamine of the liberated peptide was largely converted into pyroglutamate. The released M89b peptide (and similarly other released peptides) was purified by RP HPLC with a C12 Proteo, $10 \mu \mathrm{m}, 250 \times 21.20 \mathrm{~mm}$ column (Jupiter) using an HP 1050 HPLC system (Agilent). M89b (and similarly other peptides) was collected, after which an additional HPLC run was performed for further purification. The purified M89b peptide (and similarly other peptides) was quantified by HPLC analysis with an RP C12 Proteo, $4 \mu \mathrm{m}$, $250 \times 4.6 \mathrm{~mm}$ column (Jupiter) using a Jasco HPLC system, by comparing the $\mathrm{A}_{280}$ area of the peak with the $\mathrm{A}_{280}$ area of a known amount of galanin-(1-15) (Tocris). All HPLC runs were performed using a gradient of $10-90 \%$ acetonitrile (ACN) in $0.1 \%$ trifluoroacetic acid (TFA).

For the lanthipeptides used in the assays, a $500 \mu \mathrm{M}$ stock solution in $25 \% \mathrm{ACN} / 0.05 \%$ acetic acid was prepared from which dilutions were made in water.

\section{cAMP Assay}

To evaluate the ability of lanthipeptides to induce cAMP production via $G_{A L} R$ signaling, we used the cAMP Hunter ${ }^{\mathrm{TM}}$ eXpress $\mathrm{GAL}_{1}$ R CHO-K1 GPCR Assay from Eurofins-DiscoverX. The assay was performed according to the manufacturer's instructions. Briefly, for one assay, CHO-K1 cells expressing $\mathrm{GAL}_{1} \mathrm{R}$ were diluted in AssayComplete ${ }^{\mathrm{TM}}$ Cell Plating 2 Reagent, and $100 \mu \mathrm{l}$ was seeded into each well of a 96-well plate. The plate was incubated at $37{ }^{\circ} \mathrm{C}, 5 \% \mathrm{CO}_{2}$ in a humidified incubator. After $24 \mathrm{~h}$ of incubation, the media was aspirated, and $45 \mu \mathrm{l}$ cell assay buffer/antibody mixture was added to all wells. For the inhibition of intracellular cAMP accumulation, induced by forskolin, a serial threefold dilution of the lanthipeptides $(10 \mu \mathrm{M}$ to $5 \mathrm{nM})$ in $80 \mu \mathrm{M}$ forskolin was made. Fifteen $\mu \mathrm{l}$ of the serial dilutions was applied in duplicates to the cells. The concentration of forskolin in the assay was $20 \mu \mathrm{M}$. The agonists were incubated for $30 \mathrm{~min}$ at $37^{\circ} \mathrm{C}$. Next, $15 \mu \mathrm{L}$ Antibody Solution and $60 \mu \mathrm{L}$ cAMP Working Detection Solution were added, and the plate was incubated for $1 \mathrm{~h}$ in the dark at room temperature. Finally, $60 \mu \mathrm{L}$ cAMP Solution A was added and, after $3 \mathrm{~h}$ of incubation in the dark at room temperature, the chemiluminescent signal was read with a Synergy HT Biotek reader. 


\section{B-Arrestin Assay}

To evaluate the ability of lanthipeptides to recruit $\beta$-arrestins via $G_{A L} R$ or via $G_{1} L_{2} R$, we used the PathHunter ${ }^{\circledR}$ eXpress $\mathrm{GAL}_{1} \mathrm{R}, \mathrm{CHO}-\mathrm{K} 1, \beta$-arrestin GPCR Assay and the PathHunter ${ }^{\circledR}$ eXpress $\mathrm{GAL}_{2} \mathrm{R}, \mathrm{CHO}-\mathrm{K} 1, \beta$-arrestin, GPCR Assay from Eurofins-DiscoverX. The assays were performed according to the manufacturer's instructions. Briefly, for one assay, CHO-K1 cells co-expressing $\mathrm{GAL}_{1} \mathrm{R}$ or $\mathrm{GAL}_{2} \mathrm{R}$ and $\beta$-arrestin (isoform 2) were diluted in AssayComplete ${ }^{\mathrm{TM}}$ Cell Plating Reagent, and $100 \mu \mathrm{l}$ was seeded into each well of a 96-well plate. The plate was incubated at $37{ }^{\circ} \mathrm{C}, 5 \% \mathrm{CO}_{2}$ in a humidified incubator. A serial $3 \times$ dilution of the lanthipeptides in water was made $(10 \mu \mathrm{M}$ to $5 \mathrm{nM})$. After $48 \mathrm{~h}$ of incubation, $10 \mu \mathrm{l}$ of the serial dilutions was applied to the cells in duplicate. The agonists were incubated for $90 \mathrm{~min}$ at $37{ }^{\circ} \mathrm{C}$. Next, $55 \mu \mathrm{L}$ of Working Detection Solution was added, and after $1 \mathrm{~h}$ of incubation at room temperature in the dark, the chemiluminescent signal was read with a Synergy HT Biotek reader.

\section{Fluo-4 Direct Calcium Assay}

Calcium efflux was measured by using a Fluo-4 Direct Calcium Assay purchased from Thermo Fisher Scientific. HEK293 cells with stable overexpression of $\mathrm{GAL}_{2} \mathrm{R}$ (HEKR2) (kindly provided by Harald Dargatz, Molecular, Cellular and Pharmacobiology Section, Institute of Pharmaceutical Biology, University of Bonn, 53,115 Bonn, Germany) were used for analysis of the lanthipeptides. HEKR2 cells were seeded in a 96-well plate and grown overnight in DMEM supplemented with $10 \% \mathrm{FBS}, 1 \%$ penicillinstreptomycin, $100 \mu \mathrm{g} / \mathrm{ml}$ Normocin, and $500 \mu \mathrm{g} / \mathrm{ml} \mathrm{G} 418$ at $37^{\circ} \mathrm{C}, 5 \% \mathrm{CO}_{2}$ in a humidified incubator.

The next day, when the cells were nearly confluent, an equal amount of $2 \times$ Fluo- 4 Direct ${ }^{\mathrm{TM}}$ calcium reagent loading solution, containing $5 \mathrm{mM}$ probenecid, was added to the wells, and the plate was incubated for $1 \mathrm{~h}$ at $37^{\circ} \mathrm{C}$. A serial $3 \times$ dilution of the agonist compound in water was made, and $10 \mu \mathrm{l}$ of the serial dilutions was applied to the cells in duplicate. The starting concentration of agonist in the assay was $10 \mu \mathrm{M}$. After $1-2 \mathrm{~h}$ of incubation at room temperature, the fluorescence was measured with excitation at $485 / 20 \mathrm{~nm}$ and emission at 528/20 nm with a Synergy HT Biotek reader.

\section{Label-Free Dynamic Mass Redistribution Assay}

SH-SY5Y cells stably expressing low levels of either human GAL $_{1}$ R (SY5Y-R1) or GAL ${ }_{2}$ R (SY5Y-R2) and HEK293 cells expressing human $\mathrm{GAL}_{3} \mathrm{R}$ (HEK-R3) $[39,40]$ were seeded in EnSpire LFC-348 well plates (Perkin Elmer) at a concentration of 12,000 cells per well and cultured overnight at $37{ }^{\circ} \mathrm{C}$ and $5 \% \mathrm{CO}_{2}$. The medium was aspired, and the cells were washed four times with Hank's balanced salt solution (HBSS) (+ calcium, + magnesium) supplemented with HEPES (20 mM), and the final volume was adjusted to $30 \mu \mathrm{l}$ per well. The plate was allowed to equilibrate to assay temperature for $1 \mathrm{~h}$ in the EnSpire multimode reader (Perkin Elmer). Galanin-(1-30) (GL Biochem) was dissolved and diluted in water. Five-hundred $\mu \mathrm{M}$ stock solutions of M50b, M54, M74b, and M89b were prepared in 25\% ACN/0.05\% acetic acid from which dilutions were made in water. HBSS $(+/+)$ buffer supplemented with HEPES $(20 \mathrm{mM})$ alone or a dilution series of galanin, M50b, M54, M74b, and M89b $(1.6 \mathrm{nM}$ to $5 \mu \mathrm{M})$ dissolved in the same buffer was prepared and placed on a compound plate which was allowed to equilibrate to reach the same temperature as the EnSpire plate holding the cells. A baseline read was first generated by taking 4 measurements before ligands were added. The plate was measured between 30 and 70 repeats, and each treatment was performed in triplicate. The experiment was repeated two times for M50b and M74 and three times for M89b, $\mathrm{M} 54$, and galanin. $\mathrm{EC}_{50}$ values were calculated using Prism 8.2.0 (GraphPad Software Inc.). The values are provided as means of all independent experiments.

\section{Luciferase Reporter Assay}

The luciferase reporter assay uses a reporter plasmid and a receptor plasmid transiently transfected into the target cell line. The reporter plasmid contains a serum response element (SRE) coupled to a luciferase open reading frame and induces expression of the luciferase upon $G$ protein activation. Genetically modified HEK293 $\mathrm{G}_{\mathrm{qi}}$ cells [41] were transiently transfected with the SRE reporter and the receptor $\left(\mathrm{GAL}_{1-3} \mathrm{R}\right)$ plasmids as described previously [21, 42]. HEK293 $G_{\mathrm{qi}}$ cells and plasmids were kindly provided by Young Seong (Graduate School of Medicine, Korea University, Seoul, Republic of Korea). The cells were treated with full-length galanin (prepared as a $1 \mathrm{mM}$ stock in water containing $0.1 \%$ BSA and diluted with the same vehicle) and M89b (500 $\mu \mathrm{M}$ stock solutions were prepared in $25 \%$ ACN/0.05\% acetic acid/0.1\% BSA from which dilutions were made in water containing $0.1 \% \mathrm{BSA})(0.1 \mathrm{nM}$ to $10 \mu \mathrm{M}$ ) for $5 \mathrm{~h}$. The luciferase activity was analyzed with the Bright-Glo Luciferase Assay (Promega) in the EnSpire plate reader. The experiment was repeated three times. $\mathrm{EC}_{50}$ values were calculated using Prism 8.2.0 (GraphPad Software Inc.) and are provided as means of all independent experiments.

\section{In Vitro Stability in Rat Serum}

The stability of M89b was assessed by incubation of $10 \mu \mathrm{M}$ of the N-terminal fragment 1-15 of linear galanin (GAL(1-15)) and $10 \mu \mathrm{M} \mathrm{M} 89 \mathrm{~b}$ in 5\% rat serum buffered with $20 \mathrm{mM}$ phosphate buffer (pH 7.4) at $37^{\circ} \mathrm{C}$ for up to $23.5 \mathrm{~h}$. 
At various time points $(0,30,90,270$, and $1410 \mathrm{~min}), 180 \mu \mathrm{l}$ of samples were quenched with $10 \mu \mathrm{l} 10 \%$ TFA and $20 \mu \mathrm{l}$ $100 \%$ ACN. Samples were centrifuged and kept on ice. The amount of full-length peptides in the serum was analyzed using a C12 column $(\mathrm{C} 12 \mathrm{RP} 250 \times 4.60 \mathrm{~mm}$ column, Phenomenex) on a JASCO HPLC system and applying a gradient of $10-90 \%$ ACN in $0.1 \%$ TFA for 45 min. Peptides were detected at $280 \mathrm{~nm}$. $\mathrm{A}_{280}$ areas in chromatograms of the corresponding GAL-(1-15) and M89b full-length peptide peaks were used to determine the amount of peptide left after incubation with $5 \%$ rat serum at the different time points. Peptide peaks were determined using JASCO-Borwin Chromatography software (v1.50).

\section{In Vitro Stability in Cerebrospinal Fluid}

Pooled male Wistar Hannover rat cerebrospinal fluid was purchased from BioIVT (West Sussex, UK). Stability of peptides was analyzed by incubation of $4 \mu 10.50 \mathrm{mM}$ GAL-(1-15) with $10 \mu$ cerebrospinal fluid or $6 \mu 10.33 \mathrm{mM}$ M89b with $10 \mu \mathrm{l}$ cerebrospinal fluid at $37^{\circ} \mathrm{C}$ [43]. At various time points $(0,30,60,240$, and $480 \mathrm{~min})$, the reactions were quenched with $2 \mu \mathrm{l} 50 \%$ TFA and $20 \mu 100 \%$ ACN. Water was added to reach a final volume of $220 \mu \mathrm{l}$. Samples were centrifuged and kept on ice. Full-length peptides were quantified by using a C12 column (C12 RP $250 \times 4.60 \mathrm{~mm}$ column, Phenomenex) on a JASCO HPLC system and applying a gradient of $20-90 \%$ ACN in $0.1 \%$ TFA for $30 \mathrm{~min}$. Peptides were detected at $280 \mathrm{~nm} . \mathrm{A}_{280}$ areas in chromatograms of the corresponding GAL-(1-15) and M89b fulllength peptide peaks were used to determine the amount of peptide left after incubation with cerebrospinal fluid at the different time points. Peptide peaks were determined using JASCO-Borwin Chromatography software (v1.50).

\section{In Vitro Stability in Brain Plasma}

The method to study the stability of peptides in brain plasma is described in the Supplementary material.

\section{In Vivo Pharmacokinetics}

Pharmacokinetics studies were performed at Pharmidex UK. The animal experimental protocols were approved by the UK Government Home Office and carried out in accordance with the guidelines of the Animals (Scientific Procedures) Act (1986). Ethical approval was subject to UK Home Office license number P651A96A4.

One mg HPLC-purified and HPLC-quantified M89b was dissolved in $1 \mathrm{ml}$ Milli-Q followed by thorough vortexing and warming the solution for $10 \mathrm{~min}$ to $60{ }^{\circ} \mathrm{C}$. From this solution, a dilution in $0.1 \%$ 2-hydroxypropyl- $\beta$-cyclodextrin was made. Male CD1 mice (weighing 26.5 to $32.9 \mathrm{~g}, n=3$ per time point) were used for the pharmacokinetic studies. Mice were given $1 \mathrm{mg} / \mathrm{kg} \mathrm{M} 89 \mathrm{~b}$ either subcutaneously (s.c.) or intravenously (i.v.). Samples were collected after 2, 5, 10, $15,30,60,120$, and $240 \mathrm{~min}$. Post-dosing, the $4 \mathrm{~h}$ mice were individually housed in metabolic cages for cold collection of urine in pre-weighed tubes which were re-weighed prior to storage. At each scheduled sampling time point, terminal blood was collected from each animal by cardiac puncture in heparin-containing tubes (20 IU heparin/mL of blood) kept on wet ice. The blood was centrifuged ( $5 \mathrm{~min}$ at $21,100 \mathrm{~g}$ at $4{ }^{\circ} \mathrm{C}$ ), and the resulting plasma was transferred to the corresponding labeled polypropylene tubes prior to storage. Following blood collection, the mice were euthanized, and the brain was transferred to pre-weighed labeled polypropylene tubes which were re-weighed prior to storage. All samples were snap frozen and stored at $-70{ }^{\circ} \mathrm{C}$ prior to analysis.

\section{Preparation of Peptide Solutions for Intranasal Delivery}

For intranasal delivery, $1 \mathrm{mg}$ of M89b was first dissolved in $566 \mu \mathrm{l}$ 2,2,2-trifluorethanol, $566 \mu \mathrm{l}$ 10\% (2-hydroxypropyl)B-cyclodextrin (HBC), and $1 \mu \mathrm{l}$ acetic acid and incubated at $60{ }^{\circ} \mathrm{C}$ for $20 \mathrm{~min}$. Another $566 \mu \mathrm{l}$ of $10 \% \mathrm{HBC}$ were added. The peptide was then dried in a speed-vac, and the dried pellet was dissolved in $1132 \mu \mathrm{l}$ water by vortexing and incubation at $60^{\circ} \mathrm{C}$. M871 and GALP were purchased from GL Biochem. M871 was dissolved in saline containing 10\% HBC. GALP was dissolved in saline containing 5\% $\alpha$-cyclodextrin.

\section{Food Intake Measurement After Intranasal Application of Peptides}

In vivo experiments involving intranasal treatment of rats and measurement of feeding behavior were performed at the Institute for Translational Medicine, University of Pécs, Pécs, Hungary. Experiments were approved by the National Ethical Council for Animal Research (permit number, BA 02/2000-11/2018). They were also in accord with the directives of the European Communities Council on the protection of animals used for scientific purposes (86/609/EEC, Directive 2010/63/EU of the European Parliament and of the Council).

Spontaneous food intake was measured in non-fasted male Wistar rats ( 3 months old) for $24 \mathrm{~h}$ following intranasal application of peptide solutions by an automated FeedScale System (Columbus, OH). Each group of animals (6-9 rats/ group) was habituated to the individual chambers of the FeedScale System until daily food intake and changes in the body weight of the animals had normalized. This habituation, which lasted for a minimum of 2 weeks, allowed adaptation to the environment, to the powdered chow and to the feeder. This powdered form of chow prevented food hoarding. A special digital scale under the cages provided precise automated 
measurement and continuous recording of the amount of consumed food. During the measurement of the cumulative $24 \mathrm{~h}$ food intake, data were collected every $30 \mathrm{~min}$.

Intranasal applications were performed at 06:00 PM at the onset of the active nighttime period of rats. First, the body weight of animals was recorded, and then they were intraperitoneally anesthetized with ketamine $(52 \mathrm{mg} / \mathrm{kg}$ ) and xylazine $(9 \mathrm{mg} / \mathrm{kg})$. For the intranasal application of peptides, rats were placed on their backs, and 25-30 $\mu$ of peptide solution was injected gently per nostril (total volume of 50-60 $\mu \mathrm{l}$ per rat depending on the administered peptides) using a $10-\mu \mathrm{l}$ pipette. The following solutions were applied: M89b ( $25 \mathrm{nmol}$ in $60 \mu \mathrm{l}$ saline containing 10\% HBC); GALP (17.5 nmol in $50 \mu \mathrm{l}$ saline containing $5 \% \alpha$-cyclodextrin); M871 (219 nmol in $60 \mu \mathrm{l} 10 \% \mathrm{HBC}$ ); and M89b + M871 $(25 \mathrm{nmol} \mathrm{M} 89 \mathrm{~b}+219 \mathrm{nmol}$ M871 in $60 \mu \mathrm{l} 10 \% \mathrm{HBC})$. Control rats received the same volume of vehicle only. The total $50-60 \mu 1$ of solution per rat was given in small drops of approximately $5 \mu \mathrm{l} / \mathrm{drop}$ over a $20 \mathrm{~min}$ period, alternating drops every 2 min between the left and right nares. Complete recovery from the effects of anesthesia usually required $2 \mathrm{~h}$. Following intranasal treatment, animals were placed into their individual chamber of the FeedScale System, and measurement of the food intake was started. At $24 \mathrm{~h}$ posttreatment, the body weight of the animals was measured.

\section{Statistical Analysis}

Statistical analysis was performed with SPSS 11.0. Graphs were created using GraphPad Prism 9.0. Repeated-measures two-way ANOVA with Tukey's post hoc test was applied for the statistical analysis of the food intake data. Body weight data were analyzed by applying a one-way ANOVA with Tukey's post hoc test. Differences were accepted as statistically significant at the level of $p<0.05$. Mean \pm S.E.M. are indicated in all figures.

\section{Data availability}

The raw data supporting the conclusions of this article will be made available by the authors, without undue reservation, to any qualified researcher.

\section{Results}

\section{Design of Methyllanthionine-Stabilized Galanin Variants}

To develop a stable galanin-related variant with single GALR specificity, we introduced methyllanthionines into a Cterminally truncated galanin-related mutant, making use of bacteria containing methyllanthionine-introducing enzymes. These enzymes dehydrate threonine residues and stereospecifically couple the formed dehydrobutyrine to cysteine, after which the formed D,L-(methyl)lanthi-galanin variants, also called lanthi-galanins belonging to the class of lanthipeptides, are exported into the bacterial culture medium [44-46]. By mutagenesis, the positions of the threonine and cysteine were varied to allow the production of a large number of enzymeinstalled methyllanthionine-containing galanin variants.

As an initial screen, the biological activity of all produced variants was determined by using CHO-K1 cell lines expressing either $G_{A L} R$ or $G_{1} L_{2} R$ in commercial $\beta$-arrestin recruitment $\left(\mathrm{GAL}_{1} \mathrm{R}\right.$ or $\left.\mathrm{GAL}_{2} \mathrm{R}\right)$ and cAMP assays $\left(\mathrm{GAL}_{1} \mathrm{R}\right)$. In addition, human embryonic kidney 293 (HEK293) cell lines that express $\mathrm{GAL}_{2} \mathrm{R}$ were used to measure $\mathrm{Ca}^{2+}$ efflux. $\mathrm{GAL}_{1} \mathrm{R}$ and $\mathrm{GAL}_{2} \mathrm{R}$ were chosen because of their therapeutic potential in a range of different diseases and their involvement in appetite regulation [3].

Enzymatic introduction of a methyllanthionine consists of two steps: (1) dehydration of an engineered threonine yielding dehydrobutyrine and (2) coupling of the formed dehydrobutyrine to an engineered cysteine, thus yielding methyllanthionine. To obtain one product, instead of a mixture of peptides resulting from partial dehydration, the mutations $\mathrm{T} 3 \mathrm{~N}$ and $\mathrm{S} 6 \mathrm{~A}$ were introduced, and the peptide was found to retain significant GALR activity (Table 1). Therefore, these T3N and S6A mutations were retained in all subsequent variants.

Methyllanthionine introduction $\mathrm{N}$-terminal to position 13 abolished GALR activity (Table 2). This is consistent with the fact that these $\mathrm{N}$-terminal amino acids of galanin are essential for GALR activity [2]. Consequently, methyllanthionine introduction from position 13 onwards was

Table 1 Ratios of the half-maximal effective concentration $\left(\mathrm{EC}_{50}\right)$ of the T3N-S6A galanin variant in comparison to Gal-(1-15) in activity assays using $\mathrm{GAL}_{1} \mathrm{R}$ - and $\mathrm{GAL}_{2} \mathrm{R}$-transfected cell lines

$\mathrm{EC}_{50}$ ratios to $\mathrm{Gal}-(1-15)(\mathrm{n})$

GAL $_{1} R$

\begin{tabular}{llllll} 
Variant & Sequence & B-Arrestin & cAMP & B-Arrestin & Ca-efflux \\
\hline Wtb & GWNLNAAGYLLGPHAVGNHR & $1.6(1)$ & $1.7(2)$ & $3.8(2)$ & $2.3(2)$ \\
\hline
\end{tabular}


Table 2 Ratios of the halfmaximal effective concentration $\left(\mathrm{EC}_{50}\right)$ of the methyllanthioninecontaining galanin variants in comparison to Gal-(1-15) in activity assays using $\mathrm{GAL}_{1} \mathrm{R}$ and $\mathrm{GAL}_{2} \mathrm{R}$-transfectedcell lines

\begin{tabular}{|c|c|c|c|c|c|}
\hline \multirow[b]{2}{*}{ Variant } & \multirow[b]{2}{*}{ Sequence } & \multicolumn{2}{|c|}{$\mathbf{G A L}_{1} \mathbf{R}$} & \multicolumn{2}{|c|}{$\mathbf{G A L}_{2} \mathbf{R}$} \\
\hline & & B-Arrestin & CAMP & ß-Arrestin & Ca-eflux \\
\hline M2 & GWTLNCAGYLLGPHAVG & NA & NA & NA & NA \\
\hline M56 & GWNTNACGYLLGPHAVGNHR & NA & NA & NA & NA \\
\hline M69 & GWNLTAACYLLGPHAVGNHR & NA & NA & NA & NA \\
\hline M58 & GWNLTAAGCLLGPHAVGNHR & NA & ND & ND & NA \\
\hline M55 & GWNLNTAGCLLGPHAVGNHR & NA & ND & NA & NA \\
\hline M59 & GWNLNATGYCLGPHAVGNHR & NA & ND & NA & NA \\
\hline M61 & GWNLNAATYLCLGPHAVGNHR & NA & ND & NA & NA \\
\hline M63 & GWNLNAAGYTLGCHAVG & NA & ND & ND & NA \\
\hline
\end{tabular}

NA is not active. ND is not determined. The threonines (blue) and the cysteines (red) were post-

translationally modified in $L$. lactis yielding $D, L$ methyllanthionines. better tolerated and allowed for varying GALR specificity (Table 3).

Therefore, to keep the active lanthipeptide short, we aimed to produce methyllanthionine [13-16]. For the formation of a methyllanthionine [13-16], engineering of a dehydratable threonine at position 13 and a cysteine at position 16 is required. Since an alanine directly flanking threonine favors its dehydration by the nisin dehydratase, a G12A mutation was also introduced. These mutations allowed the enzymatic formation of dehydrobutyrine 13 and its enzymatic coupling to cysteine 16 to yield a D,L-[13-16] methyllanthionine [47, 48].

Pyroglutamate $(\mathrm{pE})$ is a natural amino acid derivative in which the free amino group of glutamine cyclizes to form a lactam. Introduction of $\mathrm{pE}$ at position 1 protects against degradation by aminopeptidases [37] other than pyroglutamate aminopeptidase [49]. Therefore, a G1Q mutation was introduced for subsequent $\mathrm{pE}$ formation. In addition, $\mathrm{N}$-terminal $\mathrm{pE}$ seems to strongly contribute to the preference of some analogs (e.g., M50b, M74b, and M89b) but not all (e.g., $\mathrm{M} 76 \mathrm{~b}$ ), for $\mathrm{GAL}_{2} \mathrm{R}$ (Table 3).

Among the peptide variants we produced, especially M50b, M54, M74b, M87, and M89b showed a preference for stimulating $\mathrm{GAL}_{2} \mathrm{R}$. While the variants M54, M74b, and M87 retained some activity toward $\mathrm{GAL}_{1} \mathrm{R}$, both $\mathrm{M} 50 \mathrm{~b}$ and M89b showed complete absence of activity toward $\mathrm{GAL}_{1}$ R-expressing cells. Importantly, M89b, a shorter peptide than M50b and thus less costly for eventual chemical synthesis, showed slightly higher activity in the $\beta$-arrestin recruitment and cAMP assays compared to M50b (Fig. 1, Table 3).

\section{Receptor Subtype Selectivity of M89b}

In the label-free assay, full-length galanin induced a change of the dynamic mass distribution (DMR) in $\mathrm{GAL}_{1} \mathrm{R}$ - and $\mathrm{GAL}_{2}$ R-transfected cell lines (SY5YR1 and SY5YR2), confirming lack of selectivity of galanin toward GALR subtypes (Fig. 2a, b). By measuring the ability of lanthipeptides to modulate the DMR of SY5YR1 and SY5YR2 cells, we confirmed that M50b and M89b stimulate $\mathrm{GAL}_{2} \mathrm{R}$ only, not $\mathrm{GAL}_{1} \mathrm{R}$; this is in contrast to M54 and M74b, which induced a very limited DMR also in SY5YR1 cells $\left(\mathrm{EC}_{50} 1.1 \mu \mathrm{M}\right.$ and $535 \mathrm{nM}$, respectively) (Fig. 2a, b). Furthermore, the halfmaximal effective concentration of $\mathrm{M} 89 \mathrm{~b}$ toward $\mathrm{GAL}_{2} \mathrm{R}$ was higher $\left(\mathrm{EC}_{50} 562 \mathrm{nM}\right)$ compared to galanin $\left(\mathrm{EC}_{50}\right.$ $255 \mathrm{nM}$ ) but was slightly lower compared to that of M50b (629 nM) (Fig. 2b). Therefore, we evaluated the activity, selectivity, and functionality of M89b, the G1pE-T3N-S6AG12A-methyllanthionine[13-16]-galanin-(1-17) variant, in more detail (Fig. 3).

Using a label-free biochip technology, we were not able to observe activation of $\mathrm{GAL}_{3} \mathrm{R}$ by galanin in HEK293 cells following doxycycline-induced overexpression of $\mathrm{GAL}_{3} \mathrm{R}$ (HEKR3) [40]. One possible explanation is that, although we observed $\mathrm{GAL}_{3} \mathrm{R}$ mRNA expression in stably transfected HEKR3 cells (data not shown), the $\mathrm{GAL}_{3} \mathrm{R}$ was not expressed on the cell surface but remained within intracellular inclusion bodies [50]. This is supported by our observation of intracellular immunoreactivity of a $\mathrm{GAL}_{3} \mathrm{R}$ antibody in HEKR3-expressing cells [51]. Therefore, we used a luciferase assay as another reporter system and transiently 
Table 3 Ratios of the half-maximal effective concentration $\left(\mathrm{EC}_{50}\right)$ of the methyllanthionine-containing galanin variants in comparison to Gal$(1-15)$ in activity assays using $\mathrm{GAL}_{1} \mathrm{R}$-and $\mathrm{GAL}_{2} \mathrm{R}$-transfected cell lines

$$
\mathrm{EC}_{50} \text { ratios to } \mathrm{Gal}-(1-15)(\mathrm{n})
$$

$\mathrm{GAL}_{1} \mathbf{R}$

\begin{tabular}{|c|c|c|c|c|c|}
\hline \multirow[b]{2}{*}{ Variant } & \multirow[b]{2}{*}{ Sequence } & \multicolumn{2}{|c|}{$\mathbf{G A L} \mathbf{R}$} & \multicolumn{2}{|c|}{$\mathbf{G A L}_{2} \mathbf{R}$} \\
\hline & & B-Arrestin & CAMP & ß-Arrestin & Ca-efflux \\
\hline M60 & GWNLNAATYLCGPHAVGNHR & $12.7(2)$ & NA (2) & NA (1) & $8.7(1)$ \\
\hline M50 & GWNLNAAGYLLATHACGNHR & $3.8(1)$ & $12.5(1)$ & $0.5(1)$ & $3.5(2)$ \\
\hline M50b & pEWNLNAAGYLLATHACGNHR & NA (1) & NA (2) & $4.7(3)$ & $2.8(3)$ \\
\hline M84 & GWNLNAAGYLLGTHACG & $35(1)$ & ND & NA (1) & $6.3(1)$ \\
\hline M89 & GWNLNAAGYLLATHACG & $148(1)$ & NA (1) & $3(1)$ & $2.7(1)$ \\
\hline M89b & pEWNLNAAGYLLATHACG & NA (3) & NA (3) & $1.7(3)$ & $1.4(3)$ \\
\hline M51 & GWNLNAAGYLLGATAVCNHR & $1.5(2)$ & $3.6(1)$ & $0.6(2)$ & $2.9(2)$ \\
\hline M54 & pEWNLNAAGYLLGATAVCNHR & $4.5(2)$ & $140(2)$ & $1.2(3)$ & $3.3(3)$ \\
\hline M54tr & pEWNLNAAGYLLGATAVCNH & NA (1) & $16(1)$ & $1(1)$ & $1.2(2)$ \\
\hline M76 & GWNLNAAGYLLGATAVGCHR & $1.0(1)$ & $0.6(1)$ & $1.0(1)$ & $0.9(1)$ \\
\hline M76b & pEWNLNAAGYLLGATAVGCHR & $9.6(1)$ & $12.2(1)$ & $0.5(1)$ & $1.0(1)$ \\
\hline M85 & GWNLNAAGYLLGPTAVC & $18.0(1)$ & $11.6(1)$ & $6.2(1)$ & $4.7(1)$ \\
\hline M87 & pEWNLNAAGYLLGPTAVC & $260(1)$ & NA (1) & $4.8(1)$ & $1.9(2)$ \\
\hline M90 & GWNLNAAGYLLGATAVC & $2.7(1)$ & $4.9(1)$ & $3.2(1)$ & $4.6(1)$ \\
\hline M91 & pEWNLNAAGYLLGATAVC & $3(1)$ & NA (1) & $1.5(1)$ & $1.3(1)$ \\
\hline M52 & GWNLNAAGYLLGPHTVGCHR & $8.3(1)$ & $7.5(2)$ & $0.6(1)$ & $1.9(1)$ \\
\hline M83 & pEWNLNAAGYLLGPHTVGCHR & $123(1)$ & NA (1) & $78(1)$ & $7.3(1)$ \\
\hline M74 & GWNLNAAGYLLGPHATGNCR & $2.3(1)$ & $4.6(1)$ & $2.6(1)$ & $4.7(1)$ \\
\hline M74b & pEWNLNAAGYLLGPHATGNCR & $129(1)$ & $13.3(1)$ & $4.2(1)$ & $2.6(3)$ \\
\hline
\end{tabular}

In each assay Gal-(1-15) was used as the reference peptide to determine the (average) $\mathrm{EC}_{50}$ ratio relative to Gal-(1-15). ND is not determined, NA is not active; ratios above 1000 were considered to be not active. The threonines (blue) and the cysteines (red) were post-translationally modified by L. lactis yielding $D, L$ methyllanthionines. The Q1pE substitutions (green) were introduced by incubation of the Q1-containing peptides in $100 \mathrm{mM}$ phosphate buffer $\mathrm{pH}$ 7.6. 
Fig. 1 M89b only stimulates $\mathrm{GAL}_{2} \mathrm{R}$ but not $\mathrm{GAL}_{1} \mathrm{R}$ signaling. $\mathrm{GAL}_{1} \mathrm{R}$-expressing CHO-K1 cells $(\mathbf{a}, \mathbf{b})$ and $\mathrm{GAL}_{2}$ R-expressing HEK293 cells $(\mathbf{c})$ or $\mathrm{CHO}-\mathrm{K} 1$ cells $(\mathbf{d})$ were used to test the ability of GAL-(1-15), M89b, M50b, and M54 (5 nM to $10 \mu \mathrm{M})$ to modulate cAMP-related luminescence (LU) (a), B-arrestin-related (b, d), or $\mathrm{Ca}^{2+}$-efflux related fluorescence $(\mathbf{c})$. Data represent mean $\pm \operatorname{SEM}(n=2)$

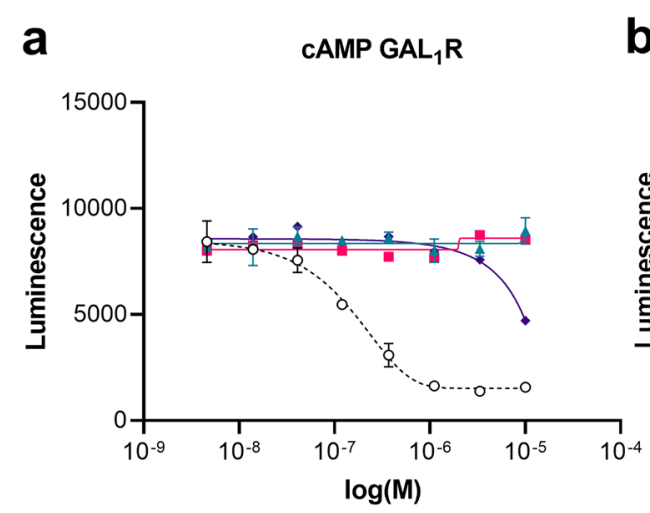

b

$\beta$-Arrestin $\mathrm{GAL}_{1} \mathbf{R}$

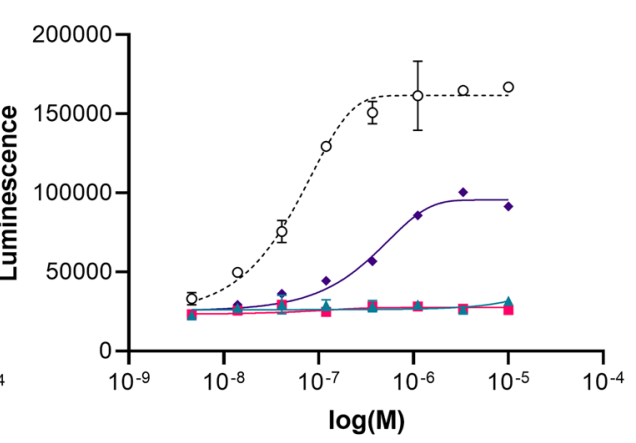

C

Ca-efflux $\mathrm{GAL}_{2} \mathrm{R}$

d

$\beta$-Arrestin $\mathrm{GAL}_{2} \mathbf{R}$
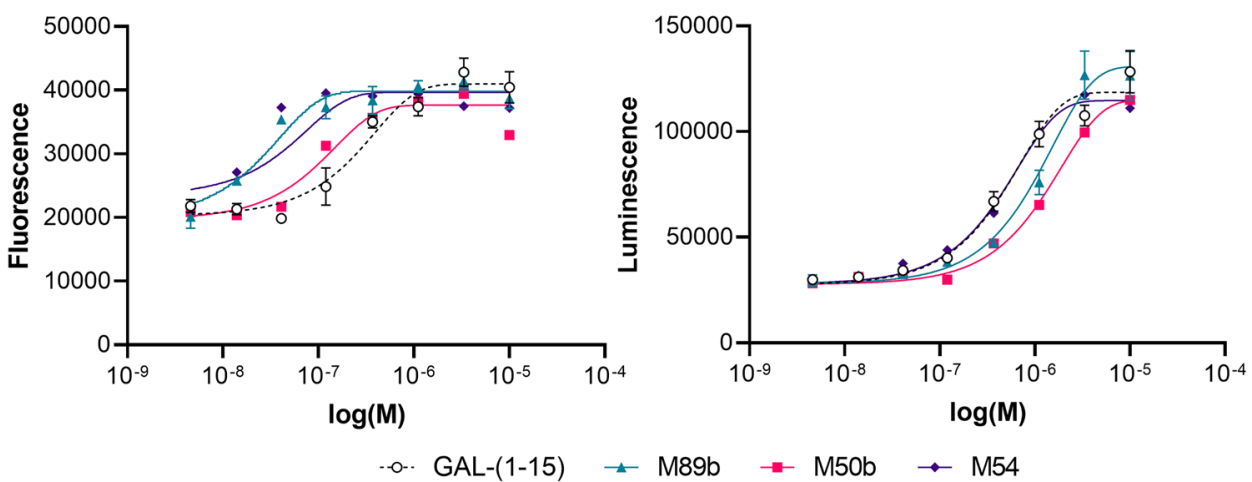

GALR-expressing cells, in which GALRs are known to be expressed on the cell surface, to detect galanin signaling via $\mathrm{GAL}_{1-3} \mathrm{R}$ [42]. Galanin induced luciferase activity in all three $\left(\mathrm{GAL}_{1-3} \mathrm{R}\right)$ transiently transfected cell lines, with mean $\mathrm{EC}_{50}$ values of $9.7 \mathrm{nM}\left(\mathrm{GAL}_{1} \mathrm{R}\right), 1.0 \mathrm{nM}\left(\mathrm{GAL}_{2} \mathrm{R}\right)$, and $828 \mathrm{nM}\left(\mathrm{GAL}_{3} \mathrm{R}\right)(\mathrm{Fig}$. $4 \mathrm{a}-\mathrm{c})$. The luciferase reporter assay confirmed the specificity of $\mathrm{M} 89 \mathrm{~b}$ for $\mathrm{GAL}_{2} \mathrm{R}\left(\mathrm{EC}_{50}\right.$ $3.7 \mathrm{nM}$ ) (Fig. 4b) and its inability to stimulate $\mathrm{GAL}_{1} \mathrm{R}$ and GAL $_{3}$ R (Fig. 4a, c).

\section{M89b Has Increased In Vitro and In Vivo Stability}

In vitro stability of M89b and the galanin fragment GAL(1-15) was tested in 5\% rat serum, cerebrospinal fluid (CSF), and brain plasma. Remarkably, in rat serum after more than $23 \mathrm{~h}$, only $40 \%$ of M89b had been degraded, and almost $60 \%$ of full-length $\mathrm{M} 89 \mathrm{~b}$ was retrieved. In contrast, already after $30 \mathrm{~min}, 80 \%$ of GAL-(1-15) was degraded, and after $90 \mathrm{~min}$, less than $2 \%$ of GAL-(1-15) was detectable (Fig. 5a). In CSF, less than $4 \%$ of GAL-(1-15) was retrieved after $4 \mathrm{~h}$, whereas almost $80 \%$ of full-length M89b were detected after $8 \mathrm{~h}$ (Fig. 5b). Finally, in brain plasma, already after $1 \mathrm{~h}$, the whole amount of GAL-(1-15) was degraded, while almost $85 \%$ of full-length M89b were still detected after $6 \mathrm{~h}$ incubation (Supplementary Figure S1). Taken together, these data demonstrate the significantly prolonged in vitro half-life of $\mathrm{M} 89 \mathrm{~b}$ in various matrices.

Next, we analyzed the pharmacokinetics of M89b. M89b $(1 \mathrm{mg} / \mathrm{kg}$ ) was applied intravenously (i.v.) or subcutaneously (s.c.) to mice, and plasma levels of M89b were measured up to $4 \mathrm{~h}$ after administration. The in vivo half-life of M89b showed marked differences after i.v. and s.c. administration (Fig. 5c). While already 30 min after i.v. application no M89b was detectable in mouse plasma, low M89b plasma levels were measured at 60 min following s.c. administration. Importantly, M89b was not detected in urine samples at $4 \mathrm{~h}$ post i.v. or s.c. injection nor in brain tissue after s.c. administration and sampled at the same time points (data not shown). This suggests that peripherally administered M89b does not cross the BBB and is not immediately secreted via the kidneys.

\section{Intranasally Delivered M89b Inhibits Acute Food Intake and Reduced Body Weight via $\mathrm{GAL}_{2} \mathrm{R}$}

The $\mathrm{GAL}_{2} \mathrm{R}$ specificity of M89b suggests it could have therapeutic potential especially when delivered to the brain. To circumvent the BBB, we examined whether M89b could be delivered intranasally, a non-invasive route of administration [52]. As galanin peptides have been shown to 
a

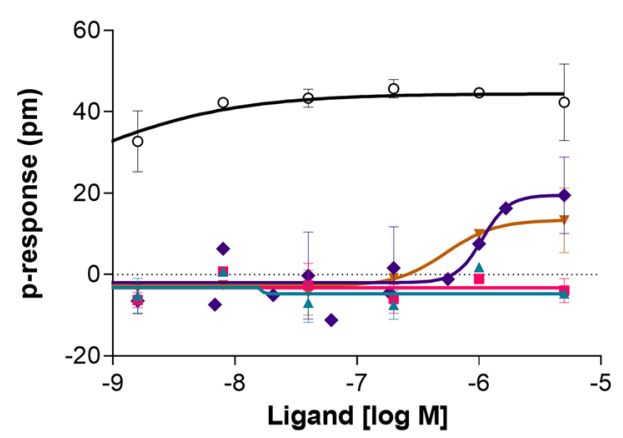

b

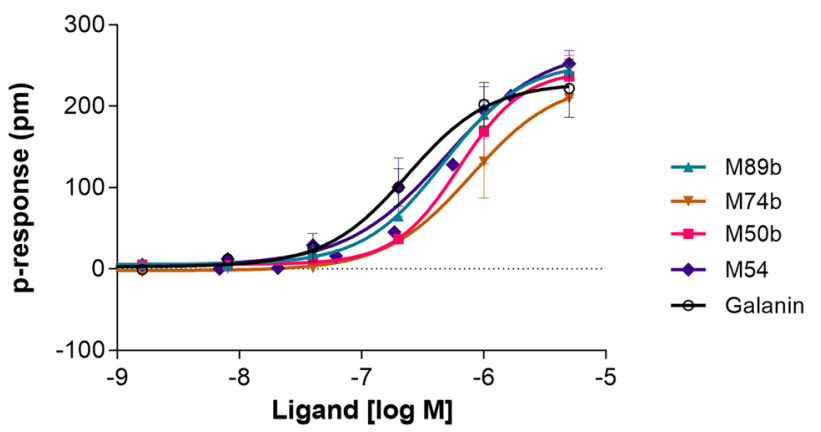

Fig. 2 Dynamic mass distribution (DMR) of $\mathrm{GAL}_{1} \mathrm{R}-$ (a) and $\mathrm{GAL}_{2} \mathrm{R}$ - (b) expressing SY5Y cells upon treatment with lanthioninestabilized galanin analogs and full-length galanin. Representative graphs showing dose-dependent change of DMR upon treatment with full-length galanin, M50b, M54, M74b, and M89b. Values represent means $\pm \operatorname{SEM}(n=1-3)$

modulate feeding, we tested the effect of M89b on acute food intake in rats. Since the efficacy of intranasal application of galanin-like-peptide (GALP) was enhanced when the peptide was complexed with $\alpha$-cyclodextrin [36], we decided to use cyclodextrins as well to enhance intranasal delivery and stability of the peptides. GALP was applied in a 5\% $\alpha$-cyclodextrin solution. M89b is very hydrophobic, but we found improved solubility could be reached in $10 \%$ (2-hydroxypropyl)-B-cyclodextrin (HBC) [53].

In accordance with the literature [52], intranasal administration of GALP (17.5 nmol) as a positive control significantly reduced 24 -h food intake in non-fasted young adult

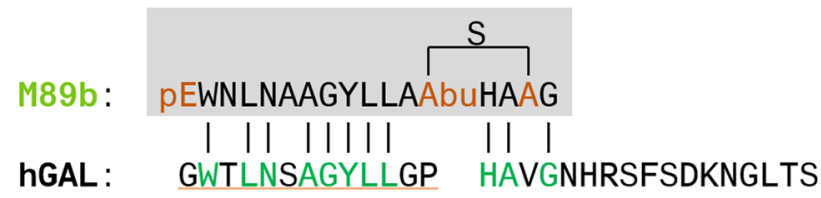

Fig. 3 The sequence of M89b. The sequence of the methyllanthioninestabilized galanin analog, M89b, in comparison to full-length human galanin (green letters indicate sequence homologous amino acids between M89b and galanin; pE, pyroglutamate; Abu-S-Ala is a methyllanthionine; Abu is aminobutyric acid)

\section{a $\quad \mathrm{GAL}_{1} \mathrm{R}$}

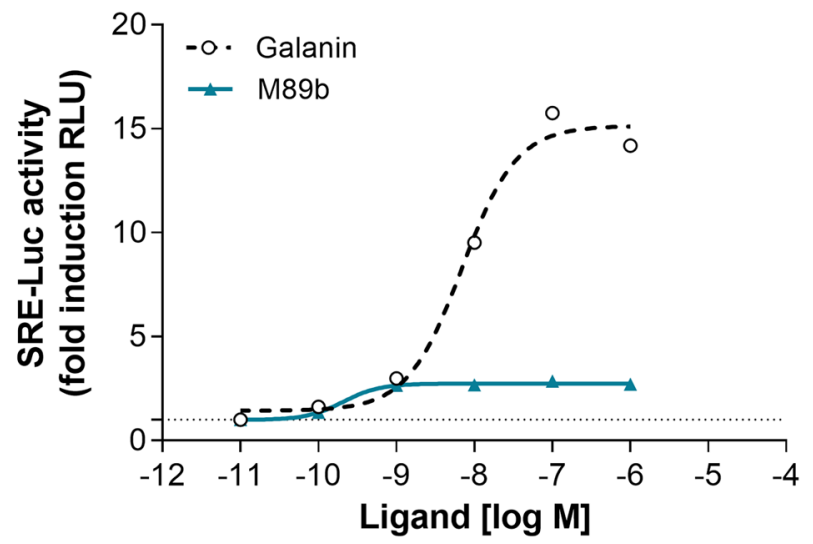

b $\mathrm{GAL}_{2} \mathbf{R}$

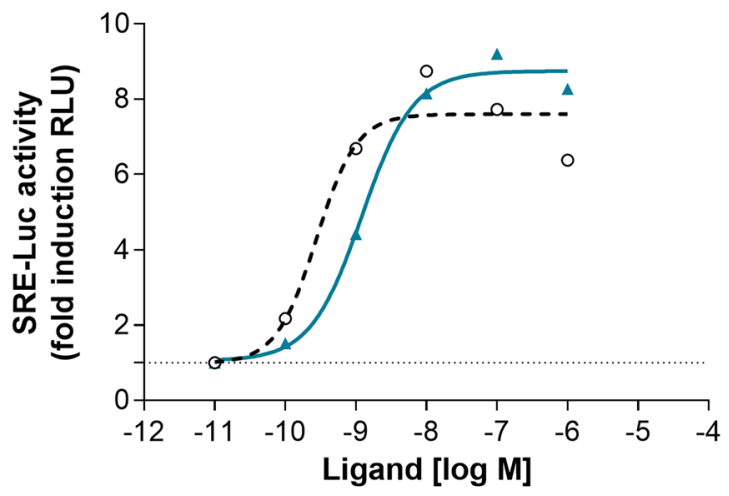

C

$\mathrm{GAL}_{3} \mathrm{R}$

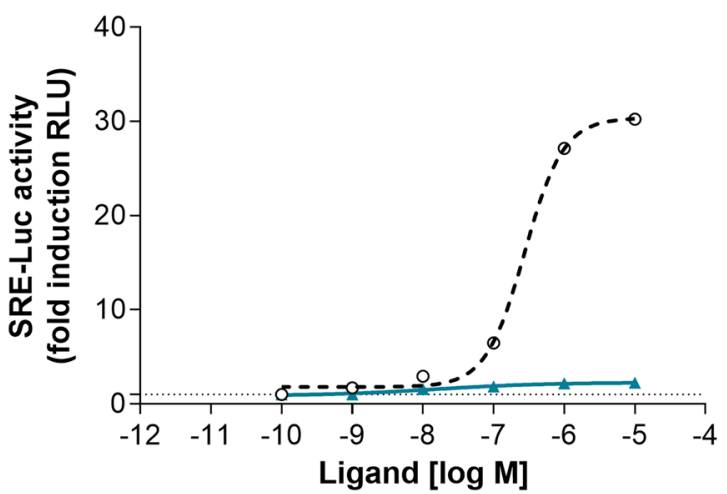

Fig. 4 Luciferase reporter assay with $\mathrm{GAL}_{1-3} \mathrm{R}$ transiently transfected HEK293 $\mathrm{G}_{\mathrm{qi}}$ cells. Graphs show representative luciferase reporter assays $(n=3)$ on $\mathrm{GAL}_{1-3}$ R-transfected HEK293 $\mathrm{G}_{\mathrm{qi}}$ cells upon treatment with full-length galanin and M89b. Luciferase activity was measured after $5 \mathrm{~h}$ of treatment with galanin or M89b in $\mathrm{GAL}_{1} \mathrm{R}-(\mathbf{a})$, $\mathrm{GAL}_{2} \mathrm{R}$ - (b), and $\mathrm{GAL}_{3} \mathrm{R}$-transfected cells $(\mathbf{c})$

rats by $19 \%$. Repeated-measures ANOVA showed a significant effect of treatment on cumulative food intake during the course of $24 \mathrm{~h}(F(1,13)=5.305 ; p=0.038)$ (Fig. 6a). The test also indicated an interaction between time and 

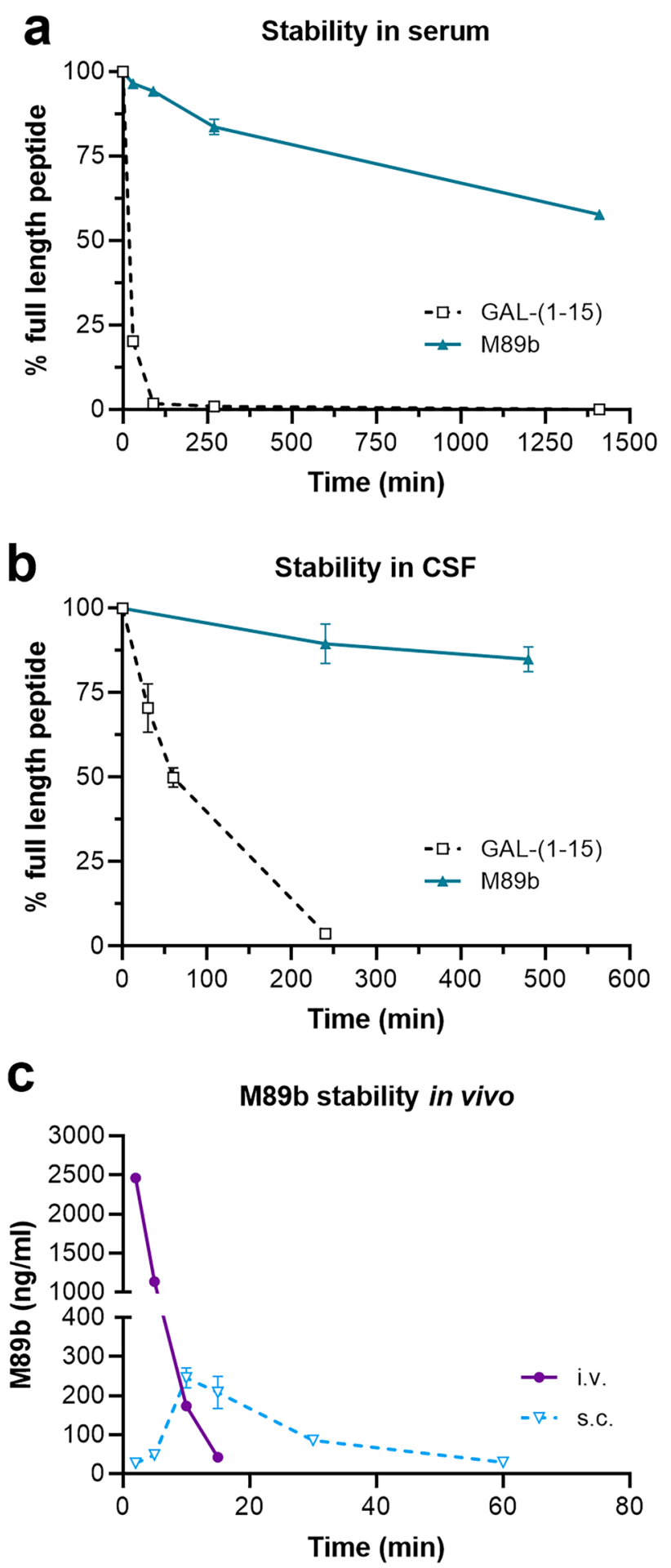

Fig. 5 M89b has increased in vitro and in vivo stability. Degradation of M89b in comparison to GAL-(1-15) in 5\% rat serum (a) and cerebrospinal fluid (b) over time and in vivo plasma levels of M89b after intravenous (i.v.) and subcutaneous (s.c.) injection of $1 \mathrm{mg} / \mathrm{kg} \mathrm{M} 89 \mathrm{~b}$ to mice (c). Data represent means \pm SEM. $n=2-3$

treatment $(p<0.001)$. The $24-\mathrm{h}$ body weight showed a trend of reduction, but this change did not reach statistical significance upon GALP treatment ( $p=0.0247$ ) (Fig. 6b). A more pronounced anorexigenic effect (an overall $23 \%$ reduction of $24 \mathrm{~h}$ food intake compared to vehicle) developed upon intranasal administration of M89b (25 nmol) (Fig. 6c). The reduction of food intake appeared after some delay. To elucidate whether the effect of M89b on cumulative food intake is indeed mediated via $\mathrm{GAL}_{2} \mathrm{R}$, we co-administered the $\mathrm{GAL}_{2} \mathrm{R}$ antagonist M871 [54]. Administration of M871 (219 nmol) alone did not influence food intake (Fig. 6c). Combined administration of M89b and M871 effectively prevented the anorexigenic effect of M89b. Repeatedmeasures ANOVA revealed a significant effect of treatment on cumulative food intake during the course of $24 \mathrm{~h}$ $[F(3,20)=6.410 ; p=0.003]$. The test also indicated an interaction between time and treatment $(p<0.001)$. Tukey's post hoc test showed significant differences between M89b- vs. all other groups (vehicle-, M871-, and M89b + M871-treated groups: $p=0.006, p=0.021$, and $p=0.008$, respectively). Remarkably, intranasal M89b also resulted in a significant reduction of body weight (Fig. 6d). At $24 \mathrm{~h}$ post-treatment, M89b-treated animals have lost $2.6 \%$ of their initial body weight ( $p=0.009$ vs. vehicle), while other treatment groups exhibited no body weight change.

\section{Discussion}

The functions of galanin-related peptides, such as galanin, GALP, and spexin, are mediated by GALRs. Over the last two decades, a wide range of GALR agonists and antagonists have been developed. Most of them displayed limited and/or unknown specificity for the three receptors $[3,55,56]$. For therapeutic application of galanin system-related ligands, receptor specificity is of upmost importance to achieve specific treatment results and to avoid unwanted side effects. Here we succeeded in designing and producing a pyroglutamate- and methyllanthionine-stabilized galanin-related agonist with strict $\mathrm{GAL}_{2} \mathrm{R}$ specificity and highly increased stability. M89b has no activity on $\mathrm{GAL}_{1} R$ or $\mathrm{GAL}_{3} R$, not even at concentrations as high as $10 \mu \mathrm{M}$, and its affinity via $\mathrm{GAL}_{2} \mathrm{R}$ is slightly lower compared to wild-type galanin or GAL-(1-15) in most assays.

Since the N-terminal region of galanin is essential for activity, our developmental approach started with a Cterminally truncated galanin analog. Accordingly, the introduction of a methyllanthionine before position 13 strongly affected activity on GALRs. Importantly, the first $\mathrm{N}$-terminal amino acid of wild-type galanin seems to have a role in receptor specificity. Its absence appears to abolish the ability of galanin to stimulate $\mathrm{GAL}_{1} \mathrm{R}$. This observation is in accordance with the fact that GAL-(2-11) is a non-GAL $\mathrm{R}_{1}$ selective GALR agonist [57, 58]. The introduction of a pyroglutamate at position 1 of our galanin analog strongly increased $\mathrm{GAL}_{2} \mathrm{R}$ affinity. Furthermore, in silico analyses indicated 

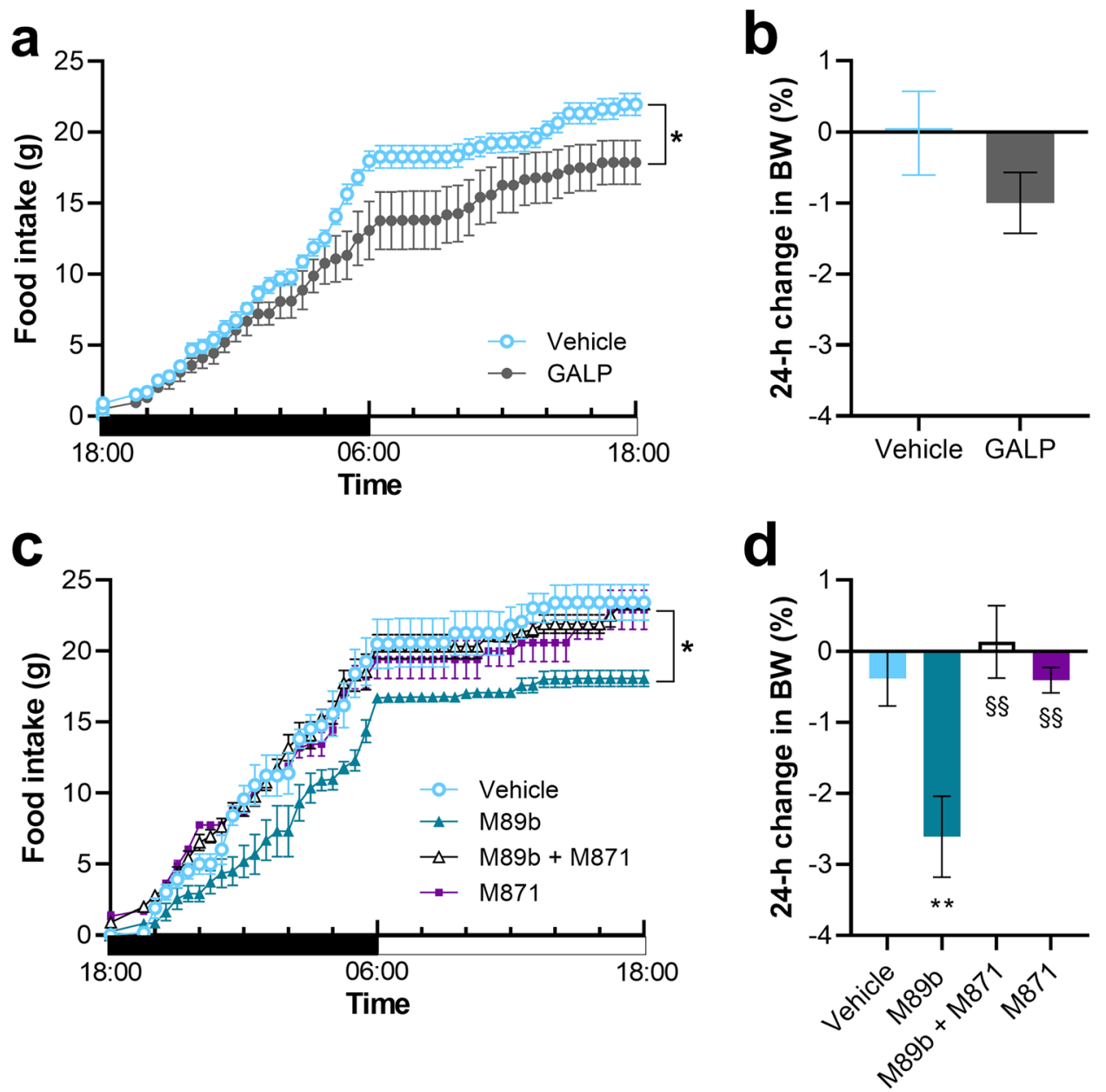

Fig. 6 Intranasally administered M89b depressed food intake and resulted in a reduced body weight (BW) in rats. A 24-h food intake was measured in non-fasted rats. During the nighttime period (black horizontal bar), intranasal GALP (17.5 nmol) slowly exerted a significant anorexigenic effect (a) without changing the body weight (b). Intranasal M89b (25 nmol) significantly reduced the $24-\mathrm{h}$ food intake in rats. Co-administration of M871 (219 nmol) completely abolished the anorexigenic effect of M89b. M871 alone had no effect on food intake (c). Compared to vehicle, M89b resulted in a significant reduc-

that the binding cavity of $\mathrm{GAL}_{2} \mathrm{R}$ is about twice the size of that of $\mathrm{GAL}_{1} \mathrm{R}$ and about three times the size of that of $\mathrm{GAL}_{3} \mathrm{R}$ [59]. The relative bulkiness of the introduced pyroglutamate and methyllanthionine might therefore contribute to the $\mathrm{GAL}_{2} \mathrm{R}$ specificity of M89b.

As expected, introduction of the pyroglutamate and the methyllanthionine clearly protected against peptidase-mediated breakdown and resulted in greatly increased stability of M89b. In an in vitro stability test using $5 \%$ serum, which contains many different peptidases [60, 61], M89b showed a half-life of over $24 \mathrm{~h}$, which is up to three times longer compared to a recently discovered spexin-based $\mathrm{GAL}_{2} \mathrm{R}$-specific agonist [21]. The increased stability in serum of the latter agonist was suggested to be due to the presence of D-amino acids. In contrast, tion of the body weight at 24-h post-treatment, whereas intranasal application of M89b + M871 or M871 alone did not change the body weight (d). Data are represented as means \pm SEM $(n=6-9)$. Food intake (a, c): $* p<0.05$, repeated-measures two-way ANOVA with Tukey's post-test. Body weight change $(\mathbf{b}, \mathbf{d})$ : body weight presented as $\%$ change at $24 \mathrm{~h}$ compared to the initial body weight. $* * p<0.01$ vs. vehicle, $\S \S p<0.01$ vs. M89b, one-way ANOVA with Tukey's post-test

M89b contains a D,L-methyllanthionine. Importantly, we could also demonstrate increased in vitro stability of M89b in rat CSF and brain plasma, which supports the in vivo activity of the peptide after administration to the brain.

Additionally, Reyes-Alcaraz et al. observed that Thr3 of wildtype galanin is critically important for activation of $\mathrm{GAL}_{2} \mathrm{R}$ and $\mathrm{GAL}_{3} \mathrm{R}$ [21]. However, in our present study, we demonstrated that a Thr3 to Asn3 mutation does not substantially influence GALR activity. Furthermore, our findings show that, after peripheral administration, M89b was not found in brain tissue or urine, the latter indicating that M89b is not immediately excreted via the kidneys. The peptide is not very cationic, which may explain the absence of detectable excretion. Alternatively, breakdown occurs prior to excretion and/or the peptide is degraded by the liver. 
Besides the spexin-based $\mathrm{GAL}_{2} \mathrm{R}$ agonist, the M1160 peptide is the only other ligand developed so far as having strict $\mathrm{GAL}_{2} \mathrm{R}$ specificity, as all others still retain activity on $\mathrm{GAL}_{1} \mathrm{R}$ and/or $\mathrm{GAL}_{3} \mathrm{R}$ at high concentrations $[62,63]$. Compared to wild-type galanin, M1160 displays a relatively low affinity toward $\mathrm{GAL}_{2} \mathrm{R}$. Importantly, no data on the stability of M1160 are available [62]. Nevertheless, M1160 showed antidepressant effects after intracerebroventricular (icv.) application in mice [62]. Spexin-based $\mathrm{GAL}_{2} \mathrm{R}$-specific variants exerted anxiolytic effects in mice [21] and therapeutic activity for mood and feeding disorders [56] after icv. administration. Interestingly, peripherally acting nonpeptidergic agonists with preferential binding to $\mathrm{GAL}_{2} \mathrm{R}$ over $G_{A L} R$ have been discovered and showed analgesic properties in rodent models of inflammation, neuropathic pain, acute pain, and epilepsy $[55,64,65]$. The selectivity of these agonists with respect to $\mathrm{GAL}_{3} \mathrm{R}$ has not been reported.

Taken together, the strict $\mathrm{GAL}_{2} \mathrm{R}$ specificity and the high in vitro stability together with the enhanced in vivo stability strongly support the clinical usefulness of M89b. Indeed, in the present study, we provide evidence that M89b is functionally active in vivo.

The galanin system plays a role in feeding, as GALRs are expressed in brain regions important for appetite control [2]. Galanin was shown to consistently stimulate food intake following acute central injection into the hypothalamic paraventricular, lateral, and ventromedial nuclei, as well as the central nucleus of the amygdala, producing a rapid increase in the feeding response. Furthermore, the literature suggests that galanin activates acute feeding behavior rather than suppressing satiety [9-12]. Although neither $\mathrm{GAL}_{1} \mathrm{R}$ - nor $\mathrm{GAL}_{2} \mathrm{R}-\mathrm{KO}$ mice displayed any marked phenotype related to feeding behavior [66, 67], an icv.-administered selective $\mathrm{GAL}_{1} \mathrm{R}$ agonist, M617, induced consumption of high-fat milk in rats, whereas a selective $\mathrm{GAL}_{2} \mathrm{R}$ agonist, M1153, did not [68]. However, it has to be noted that both of these two agonists retain some activity on other GALR subtypes. Interestingly, GALP was shown to reduce food intake in wild-type mice, as well as in $\mathrm{GAL}_{1} \mathrm{R}$ - and $\mathrm{GAL}_{2} \mathrm{R}-\mathrm{KO}$ mice [69], indicating that the effect of GALP on feeding behavior might not be exclusively mediated by GALR signaling. Furthermore, an anti-obesity effect of GALP after intranasal administration was shown [52]. Thus, we used GALP in the present study as a positive control and confirmed its anorexigenic effect resulting in a trend of weight loss that did not reach statistical significance. Importantly, we found that intranasally delivered M89b reduced acute food intake and 24-h body weight in rats, thus demonstrating M89b activity in vivo. A possible increase in metabolic rate could contribute to the stronger weight loss in case of M89b administration. The effects on food intake and body weight were abolished by co-administration of the
$\mathrm{GAL}_{2} \mathrm{R}$-specific antagonist M871. To our knowledge, this is the first study showing in vivo activity of a lanthionine peptide upon intranasal application. Furthermore, our data support recent findings on a $\mathrm{GAL}_{2} \mathrm{R}$-selective spexin analog [56], which indicates that the regulation of food intake by GALP and spexin is mediated by $\mathrm{GAL}_{2} \mathrm{R}$ signaling. However, there are no studies available which tried to block the effects of GALP on food intake with GALR-specific antagonists to prove the involvement of GALRs in GALPmediated effects. As chronic administration might lead to resistance to treatment, it will have to be elucidated whether chronic administration of M89b reduces the body weight of obese animals. A first hint that this could be the case comes from the observation that intranasal administration of the spexin-based $\mathrm{GAL}_{2} \mathrm{R}$ agonist $\mathrm{SG} 2 \mathrm{~A}$ for 14 days decreased food intake and body weight [56]. Taken together, these data indicate that, depending on the route of administration and type of receptor activated, GALR signaling might have either orexigenic or anorexigenic effects.

Intranasal delivery of peptides to the brain has been reported for a limited number of peptides [35], including GALP [52]. This method is clearly less invasive than many other routes of peptide administration to the brain. The key requirement of reaching effective levels at the intended brain areas appears to have been met by intranasal delivery of M89b, which reduced food intake and body weight. Further studies using labeled M89b may assess the exact distribution of the nasally delivered peptide.

In conclusion, intranasal delivery of a $\mathrm{GAL}_{2} \mathrm{R}$-selective agonist offers therapeutic opportunities for treating a variety of brain diseases. $\mathrm{GAL}_{2} \mathrm{R}$ has, for instance, been reported to be neuroprotective in experimental autoimmune encephalomyelitis and a cuprizone model mimicking aspects of multiple sclerosis [70, 71]. A non-functional $\mathrm{GAL}_{2} \mathrm{R}$ in a multiple sclerosis patient has been reported [72], indicating a potential therapeutic role for stimulation of $\mathrm{GAL}_{2} \mathrm{R}$ in this disease. The current study raises the possibility of an antiobesity effect of M89b that could be confirmed via chronic or repeated administration in future studies.

Supplementary Information The online version contains supplementary material available at https://doi.org/10.1007/s13311-021-01155-x.

Acknowledgements Genetically modified HEK293 $\mathrm{G}_{\mathrm{qi}}$ cells and $\left(\mathrm{GAL}_{1-3} \mathrm{R}\right)$ plasmids were kindly provided by Young Seong (Graduate School of Medicine, Korea University, Seoul, Republic of Korea).

Required Author Forms Disclosure forms provided by the authors are available with the online version of this article.

Author Contribution B. K. and G. N. M. designed the study. A. K., M. B., E. P., A. K., and S. M. B. performed the research. A. K., M. B., E. P., A. K., and S. M. B. analyzed the data. B. K. and S. M. B. wrote the paper, and G. N. M. contributed to writing. All authors critically revised and approved the final manuscript. 
Funding Open access funding provided by Paracelsus Medical University. This work was supported by the University of Pecs, Hungary (PTE ÁOK-KA No: 2019/44 to E. P.) and by the Austrian Research Promotion Agency (FFG, 822782/THERAPEP to B. K.).

Data Availability The raw data supporting the conclusions of this article will be made available by the authors, without undue reservation, to any qualified researcher.

\section{Declarations}

Competing Interest A. K. and G. N. M. are employees of Lanthio Health B.V., which is the owner of a patent on lanthionine-stabilized galanins. G. N. M. is the owner of Lanthio Participatie B.V.

Open Access This article is licensed under a Creative Commons Attribution 4.0 International License, which permits use, sharing, adaptation, distribution and reproduction in any medium or format, as long as you give appropriate credit to the original author(s) and the source, provide a link to the Creative Commons licence, and indicate if changes were made. The images or other third party material in this article are included in the article's Creative Commons licence, unless indicated otherwise in a credit line to the material. If material is not included in the article's Creative Commons licence and your intended use is not permitted by statutory regulation or exceeds the permitted use, you will need to obtain permission directly from the copyright holder. To view a copy of this licence, visit http://creativecommons.org/licenses/by/4.0/.

\section{References}

1. Tatemoto K, Rokaeus A, Jornvall H, McDonald TJ, Mutt V. Galanin - a novel biologically active peptide from porcine intestine. FEBS Lett 1983;164:124-128.

2. Lang R, Gundlach AL, Kofler B. The galanin peptide family: receptor pharmacology, pleiotropic biological actions, and implications in health and disease. Pharmacol Ther 2007;115:177-207.

3. Lang R, Gundlach AL, Holmes FE, et al. Physiology, signaling, and pharmacology of galanin peptides and receptors: three decades of emerging diversity. Pharmacol Rev 2015;67:118-175.

4. Koller A, Bianchini R, Schlager S, Munz C, Kofler B, Wiesmayr $\mathrm{S}$. The neuropeptide galanin modulates natural killer cell function. Neuropeptides 2017;64:109-115.

5. Locker F, Lang AA, Koller A, Lang R, Bianchini R, Kofler B. Galanin modulates human and murine neutrophil activation in vitro. Acta Physiol (Oxf) 2015;213:595-602.

6. Ramspacher A, Neudert M, Koller A, Schlager S, Kofler B, Brunner $\mathrm{SM}$. Influence of the regulatory peptide galanin on cytokine expression in human monocytes. Annals of the New York Academy of Sciences 2019;1455:185-195.

7. Koller A, Brunner SM, Bianchini R, et al. Galanin is a potent modulator of cytokine and chemokine expression in human macrophages. Sci Rep 2019;9:7237.

8. Kyrkouli SE, Stanley BG, Leibowitz SF. Galanin: stimulation of feeding induced by medial hypothalamic injection of this novel peptide. European journal of pharmacology 1986;122:159-160.

9. Kyrkouli SE, Stanley BG, Seirafi RD, Leibowitz SF. Stimulation of feeding by galanin: anatomical localization and behavioral specificity of this peptide's effects in the brain. Peptides 1990;11:995-1001.
10. Crawley JN. The role of galanin in feeding behavior. Neuropeptides 1999;33:369-375.

11. Corwin RL, Robinson JK, Crawley JN. Galanin antagonists block galanin-induced feeding in the hypothalamus and amygdala of the rat. Eur J Neurosci 1993;5:1528-1533.

12. Schick RR, Samsami S, Zimmermann JP, et al. Effect of galanin on food intake in rats: involvement of lateral and ventromedial hypothalamic sites. Am J Physiol 1993;264:R355-R361.

13. Jacoby AS, Hort YJ, Constantinescu G, Shine J, Iismaa TP. Critical role for GALR1 galanin receptor in galanin regulation of neuroendocrine function and seizure activity. Mol Brain Res 2002; 107:195-200.

14. Gottsch ML, Zeng H, Hohmann JG, Weinshenker D, Clifton DK, Steiner RA. Phenotypic analysis of mice deficient in the type 2 galanin receptor (GALR2). Mol Cell Biol 2005;25:4808-4811.

15. Wynick D, Bacon A. Targeted disruption of galanin: new insights from knock-out studies. Neuropeptides 2002;36:132-144.

16. Zorrilla EP, Brennan M, Sabino V, Lu X, Bartfai T. Galanin type 1 receptor knockout mice show altered responses to high-fat diet and glucose challenge. Physiol Behav 2007;91:479-485.

17. Adams AC, Clapham JC, Wynick D, Speakman JR. Feeding behaviour in galanin knockout mice supports a role of galanin in fat intake and preference. Journal of neuroendocrinology 2008;20:199-206.

18. Fuxe K, Marcellino D, Rivera A, et al. Receptor-receptor interactions within receptor mosaics. Impact on neuropsychopharmacology. Brain Res Rev 2008;58:415-452.

19. Fuxe K, Borroto-Escuela DO, Romero-Fernandez W, et al. On the existence and function of galanin receptor heteromers in the central nervous system. Front Endocrinol (Lausanne) 2012;3:127.

20. Webling K, Runesson J, Lang A, Saar I, Kofler B, Langel U. Ala5galanin $(2-11)$ is a GAL2R specific galanin analogue. Neuropeptides 2016;60:75-82.

21. Reyes-Alcaraz A, Lee YN, Son GH, et al. Development of Spexinbased Human Galanin Receptor Type II-Specific Agonists with Increased Stability in Serum and Anxiolytic Effect in Mice. Sci Rep 2016;6:21453.

22. Bedecs $\mathrm{K}$, Langel U, Bartfai T. Metabolism of galanin and galanin (1-16) in isolated cerebrospinal fluid and spinal cord membranes from rat. Neuropeptides 1995;29:137-143.

23. Holst JJ, Bersani M, Hvidberg A, et al. On the effects of human galanin in man. Diabetologia 1993;36:653-657.

24. Carey DG, Iismaa TP, Ho KY, et al. Potent effects of human galanin in man: growth hormone secretion and vagal blockade. The Journal of clinical endocrinology and metabolism 1993;77:90-93.

25. de Vries L, Reitzema-Klein CE, Meter-Arkema A, et al. Oral and pulmonary delivery of thioether-bridged angiotensin-(1-7). Peptides 2010;31:893-898.

26. Bosma T, Kuipers A, Bulten E, de Vries L, Rink R, Moll GN Bacterial display and screening of posttranslationally thioetherstabilized peptides. Appl Environ Microbiol 2011;77:6794-6801.

27. Kluskens LD, Nelemans SA, Rink R, et al. Angiotensin-(1-7) with thioether bridge: an angiotensin-converting enzyme-resistant, potent angiotensin-(1-7) analog. J Pharmacol Exp Ther 2009;328:849-854.

28. Bosma T, Rink R, Moosmeier MA, Moll GN. Genetically Encoded Libraries of Constrained Peptides. Chembiochem 2019;20:1754-1758.

29. Kuipers A, Moll GN, Levy A, Krakovsky M, Franklin R. Cyclic angiotensin-(1-7) contributes to rehabilitation of animal performance in a rat model of cerebral stroke. Peptides 2020;123:170193.

30. Kuipers A, Moll GN, Wagner E, Franklin R. Efficacy of lanthionine-stabilized angiotensin-(1-7) in type I and type II diabetes mouse models. Peptides 2019;112:78-84. 
31. Durik M, van Veghel R, Kuipers A, et al. The effect of the thioether-bridged, stabilized Angiotensin-(1-7) analogue cyclic ang-(1-7) on cardiac remodeling and endothelial function in rats with myocardial infarction. Int J Hypertens 2012;2012:536426.

32. Wösten-van Asperen RM, Lutter R, Specht PA, et al. Acute respiratory distress syndrome leads to reduced ratio of ACE/ACE2 activities and is prevented by angiotensin-(1-7) or an angiotensin II receptor antagonist. J Pathol 2011;225:618-627.

33. Nonaka N, Farr SA, Kageyama H, Shioda S, Banks WA. Delivery of galanin-like peptide to the brain: targeting with intranasal delivery and cyclodextrins. J Pharmacol Exp Ther 2008;325:513-519.

34. Medina G, Ji G, Gregoire S, Neugebauer V. Nasal application of neuropeptide $\mathrm{S}$ inhibits arthritis pain-related behaviors through an action in the amygdala. Mol Pain 2014;10:32.

35. Meredith ME, Salameh TS, Banks WA. Intranasal Delivery of Proteins and Peptides in the Treatment of Neurodegenerative Diseases. AAPS J 2015;17:780-787.

36. Takenoya F, Hirako S, Wada N, et al. Regulation of Feeding Behavior and Energy Metabolism by Galanin-like Peptide (GALP): A Novel Strategy to Fight Against Obesity. Curr Pharm Des 2018;24:3926-3933.

37. Rink R, Arkema-Meter A, Baudoin I, et al. To protect peptide pharmaceuticals against peptidases. J Pharmacol Toxicol Methods 2010;61:210-218.

38. Terzaghi BE, Sandine WE. Improved medium for lactic streptococci and their bacteriophages. Appl Microbiol 1975;29:807-813.

39. Berger A, Lang R, Moritz K, et al. Galanin receptor subtype GalR2 mediates apoptosis in SH-SY5Y neuroblastoma cells. Endocrinology 2004; 145:500-507.

40. Brunner SM, Koller A, Stockinger J, et al. Validation of antibodybased tools for galanin research. Peptides 2019;120:170009.

41. Conklin BR, Farfel Z, Lustig KD, Julius D, Bourne HR. Substitution of three amino acids switches receptor specificity of $\mathrm{Gq}$ alpha to that of Gi alpha. Nature 1993;363:274-276.

42. Kim DK, Yun S, Son GH, et al. Coevolution of the spexin/galanin/ kisspeptin family: Spexin activates galanin receptor type II and III. Endocrinology 2014;155:1864-1873.

43. Murza A, Belleville K, Longpre JM, Sarret P, Marsault E. Stability and degradation patterns of chemically modified analogs of apelin-13 in plasma and cerebrospinal fluid. Biopolymers 2014;102:297-303.

44. Kuipers A, de Boef E, Rink R, et al. NisT, the transporter of the lantibiotic nisin, can transport fully modified, dehydrated, and unmodified prenisin and fusions of the leader peptide with non-lantibiotic peptides. J Biol Chem 2004;279:22176-22182.

45. Kluskens LD, Kuipers A, Rink R, et al. Post-translational modification of therapeutic peptides by NisB, the dehydratase of the lantibiotic nisin. Biochemistry 2005;44:12827-12834.

46. Rink R, Kluskens LD, Kuipers A, Driessen AJ, Kuipers OP, Moll GN. NisC, the cyclase of the lantibiotic nisin, can catalyze cyclization of designed nonlantibiotic peptides. Biochemistry 2007;46:13179-13189.

47. Rink R, Kuipers A, de Boef E, et al. Lantibiotic structures as guidelines for the design of peptides that can be modified by lantibiotic enzymes. Biochemistry 2005;44:8873-8882.

48. Rink R, Wierenga J, Kuipers A, et al. Production of dehydroamino acid-containing peptides by Lactococcus lactis. Appl Environ Microbiol 2007;73:1792-1796.

49. Gong Q, Li L, Wu X, Ma H. Pyroglutamate aminopeptidase 1 may be an indicator of cellular inflammatory response as revealed using a sensitive long-wavelength fluorescent probe. Chem Sci 2016;7:4694-4697.

50. Robinson J, Smith A, Sturchler E, Tabrizifard S, Kamenecka T, McDonald P. Development of a high-throughput screening- compatible cell-based functional assay to identify small molecule probes of the galanin 3 receptor (GalR3). Assay Drug Dev Technol 2013;11:468-477.

51. Schrodl F, Kaser-Eichberger A, Trost A, et al. Distribution of galanin receptors in the human eye. Exp Eye Res 2015;138:42-51.

52. Kageyama H, Shiba K, Hirako S, et al. Anti-obesity effect of intranasal administration of galanin-like peptide (GALP) in obese mice. Sci Rep 2016;6:28200.

53. Lula I, Denadai AL, Resende JM, et al. Study of angiotensin-(1-7) vasoactive peptide and its beta-cyclodextrin inclusion complexes: complete sequence-specific NMR assignments and structural studies. Peptides 2007;28:2199-2210.

54. Sollenberg U, Lindström L, Bartfai T, Langel U. M871-A novel peptide antagonist selectively recognizing the galanin receptor type 2 Int J Pept Res Ther 2006;12:115-119.

55. Metcalf CS, Smith MD, Klein BD, McDougle DR, Zhang L, Bulaj G. Preclinical Analgesic and Safety Evaluation of the GalR2-preferring Analog, NAX 810-2. Neurochem Res 2017;42:1983-1994.

56. Yun S, Reyes-Alcaraz A, Lee YN, et al. Spexin-Based Galanin Receptor Type 2 Agonist for Comorbid Mood Disorders and Abnormal Body Weight. Front Neurosci 2019;13:391.

57. Liu HX, Brumovsky P, Schmidt R, et al. Receptor subtype-specific pronociceptive and analgesic actions of galanin in the spinal cord: selective actions via GalR1 and GalR2 receptors. Proc Natl Acad Sci U S A 2001;98:9960-9964.

58. Lu X, Lundstrom L, Bartfai T. Galanin (2-11) binds to GalR3 in transfected cell lines: limitations for pharmacological definition of receptor subtypes. Neuropeptides 2005;39:165-167.

59. Jurkowski W, Yazdi S, Elofsson A. Ligand binding properties of human galanin receptors. Mol Membr Biol 2013;30:206-216.

60. Szczeklik A, Szewczuk A, Nowosad H, Kolaczkowska B. Serum peptidases in myocardial infarction. Br Heart J 1972;34:232-237.

61. Kim HY, Hwang JI, Moon MJ, Seong JY. A Novel Long-Acting Glucagon-Like Peptide-1 Agonist with Improved Efficacy in Insulin Secretion and beta-Cell Growth. Endocrinol Metab (Seoul) 2014;29:320-327.

62. Saar I, Runesson J, Jarv J, Kurrikoff K, Langel U. Novel galanin receptor subtype specific ligand in depression like behavior. Neurochem Res 2013;38:398-404.

63. Webling KE, Runesson J, Bartfai T, Langel U. Galanin receptors and ligands. Front Endocrinol (Lausanne) 2012;3:146.

64. Metcalf CS, Klein BD, McDougle DR, et al. Analgesic properties of a peripherally acting and GalR2 receptor-preferring galanin analog in inflammatory, neuropathic, and acute pain models. J Pharmacol Exp Ther 2015;352:185-193.

65. White HS, Scholl EA, Klein BD, et al. Developing novel antiepileptic drugs: characterization of NAX 5055, a systemically-active galanin analog, in epilepsy models. Neurotherapeutics 2009;6:372-380.

66. Jacoby AS, Hort YJ, Constantinescu G, Shine J, Iismaa TP. Critical role for GALR1 galanin receptor in galanin regulation of neuroendocrine function and seizure activity. Brain Res Mol Brain Res 2002; 107:195-200.

67. Gottsch ML, Zeng H, Hohmann JG, Weinshenker D, Clifton DK, Steiner RA. Phenotypic analysis of mice deficient in the type 2 galanin receptor (GALR2). Mol Cell Biol 2005;25:4804-4811.

68. Saar I, Runesson J, McNamara I, Jarv J, Robinson JK, Langel U. Novel galanin receptor subtype specific ligands in feeding regulation. Neurochem Int 2011;58:714-720.

69. Krasnow SM, Hohmann JG, Gragerov A, Clifton DK, Steiner RA. Analysis of the contribution of galanin receptors 1 and 2 to the central actions of galanin-like peptide. Neuroendocrinology 2004;79:268-277. 
70. Wraith DC, Pope R, Butzkueven $\mathrm{H}$, et al. A role for galanin in human and experimental inflammatory demyelination. Proc Natl Acad Sci U S A 2009;106:15466-15471.

71. Zhang L, Yu W, Schroedter I, Kong J, Vrontakis M. Galanin transgenic mice with elevated circulating galanin levels alleviate demyelination in a cuprizone-induced MS mouse model. PLoS One 2012;7:e33901.
72. Garcia-Rosa S, Trivella DB, Marques VD, et al. A non-functional galanin receptor- 2 in a multiple sclerosis patient. Pharmacogenomics J 2019;19:72-82.

Publisher's Note Springer Nature remains neutral with regard to jurisdictional claims in published maps and institutional affiliations. 